\title{
Inositol Phosphate Receptors and Calcium Disposition in the Brain
}

\author{
Christopher D. Ferris and Solomon H. Snyder \\ Departments of Neuroscience, Pharmacology and Molecular Sciences, Psychiatry, and Behavioral Sciences, The Johns \\ Hopkins University Medical Institutions, Baltimore, Maryland 21205
}

In recent years it has become increasingly apparent that the phosphoinositide (PI) cycle represents a major second messenger system, comparable in importance to cAMP for actions of hormones, neurotransmitters, and other regulatory molecules. The PI cycle responds to the actions of an agonist at a membrane receptor that, via coupling to a $\mathrm{G}$-protein, triggers the hydrolysis of phosphatidylinositol bisophosphate, resulting in the generation of inositol 1,4,5-trisphosphate $\left(\mathrm{IP}_{3}\right)$ and diacylglycerol (DAG). DAG enhances the activity of protein kinase $C$ (PKC) by rendering it more sensitive to stimulation by $\mathrm{Ca}^{2+}$ (Nishizuka, 1988), while $\mathrm{IP}_{3}$ stimulates the release of $\mathrm{Ca}^{2+}$ from endoplasmic reticulum (ER) stores (Berridge, 1987; Berridge and Irvine, 1989). The $\mathrm{Ca}^{2+}$ released by $\mathrm{IP}_{3}$ stimulation activates many calcium-dependent processes. For instance, it enhances the phosphorylation of diverse substrates by $\mathrm{PKC}$. $\mathrm{IP}_{3}$ can be further phosphorylated to form inositol 1,3,4,5-tetrakisphosphate $\left(\mathrm{IP}_{4}\right)$, inositol 1,3,4,5,6-pentakisphosphate $\left(\mathrm{IP}_{5}\right)$, and inositol hexakisphosphate $\left(\mathrm{IP}_{6}\right)$. These higher inositol phosphates are present in the brain and other tissues in concentrations comparable to those of $\mathrm{IP}_{3}$, and so they may have comparably important functions, which have not been established, however.

Clarification of physiological functions for the PI cycle has emerged mainly from studies of PI metabolism or turnover in response to various stimuli. In brain tissue, PI turnover had usually been monitored by labeling the inositol-containing phospholipids with the precursor ${ }^{3} \mathrm{H}$-inositol (Berridge et al., 1982). At the steady state, ${ }^{3} \mathrm{H}$-inositol is present in the various inositol phosphates, whose levels can be monitored in various ways. It is also possible to monitor PI turnover by using ${ }^{3} \mathrm{H}$-cytidine as an IP precursor. Cytidine feeds into the PI cycle via cytidine diphosphate diacylglycerol (CDP-DAG), whose levels increase with the rate of PI turnover (Godfrey, 1989). Since CDP-DAG is membrane bound, ${ }^{3} \mathrm{H}-\mathrm{CDP}-\mathrm{DAG}$ localization by autoradiography can monitor PI turnover at the cellular level (Hwang et al., 1990). Such autoradiographic localization in the cerebellum reveals selective glutamatergic stimulation of PI turnover in Purkinje cells and their processes. In the hippocampus, both muscarinic cholinergic stimulation and glutamatergic stimulation increase PI turnover, but their sites of action differ, with

\footnotetext{
This work was supported by USPHS Grant MH-18501, Research Scientist Award DA-00074 to S.H.S., Predoctoral Fellowship MH-10018 to C.D.F., a grant of the International Life Sciences Institute, and a gift from Bristol-Myers Squibb.

Correspondence should be addressed to Dr. Solomon H. Snyder, Department of Neuroscience, Johns Hopkins University School of Medicine, 725 North Wolfe Strect, Baltimore, MD 21205.
}

Copyright $\subset$ C 1992 Society for Neuroscience $0270-6474 / 92 / 121567-08 \$ 05.00 / 0$ cholinergic stimulation affecting CA1, CA3, and CA4, and the subiculum, whereas glutamatergic stimulation is restricted to CA3 and the subiculum (Hwang et al., 1990). While many studies have monitored PI turnover, few measured endogenous levels of the inositol phosphates, largely because of technical difficulties. The high affinity and specificity of $\mathrm{IP}_{3}$ receptors for $\mathrm{IP}_{3}$ have facilitated development of a simple and specific radioreceptor assay for $\mathrm{IP}_{3}$ (Bredt et al., 1989; Challiss et al., 1990). In this assay, endogenous $\mathrm{IP}_{3}$ in protein-free tissue extracts competes with added exogenous ${ }^{3} \mathrm{H}-\mathrm{IP}_{3}$ for binding to receptors in crude preparations of cerebellar or adrenal membranes, providing selectivity for the physiologic form of $\mathrm{IP}_{3}$ and detection of low nanomolar concentrations. Similar procedures allow radioreceptor assays for $\mathrm{IP}_{4}$ (Donie and Reiser, 1989; Challiss and Nahorski, 1990).

\section{Inositol phosphate receptor characterization and isolation}

The first attempts to label $\mathrm{IP}_{3}$ receptors by ligand binding utilized peripheral tissues such as neutrophils, liver, and adrenal membranes (Baukal et al., 1985; Spat et al., 1986; Guillemette et al., 1987). The relatively low levels of specific $\mathbf{I P}_{3}$ binding in these tissues precluded their direct biochemical characterization. By utilizing autoradiography to detect receptor bound ${ }^{3} \mathrm{H}$ $\mathrm{IP}_{3}$, much higher levels of $\mathrm{IP}_{3}$ receptors were found in the CNS, where they are present at a very high density in the Purkinje cells of the cerebellum, the tissue source presently utilized for most biochemical studies of $\mathrm{IP}_{3}$ receptors (Worley et al., 1987a, 1989). The inositol phosphate specificity of the cerebellar $\mathrm{IP}_{3}$ receptor is essentially the same as that of peripheral tissues (Berridge, 1987; Berridge and Irvine, 1989).

Several properties of $\mathrm{IP}_{3}$ receptors appear to reflect their physiologically important regulatory function. For instance, physiologic levels of $\mathrm{Ca}^{2+}$ inhibit $\mathrm{IP}_{3}$ binding to its receptor with an $\mathrm{IC}_{50}$ of about $300 \mathrm{~nm}$ (Worley et al., 1987b; Danoff et al., 1988). This finding implies that $\mathrm{Ca}^{2}+$ released by $\mathrm{IP}_{3}$ feeds back to inhibit further stimulation of $\mathrm{Ca}^{2+}$ release by $\mathrm{IP}_{3}$. Increases in intracellular $\mathrm{pH}$ from 7.5 to 8.5 cause a tripling in $\mathrm{IP}_{3}$ binding to its receptor (Worley et al., 1987b). Increases in intracellular $\mathrm{pH}$ also augment the ability of $\mathrm{IP}_{3}$ to release $\mathrm{Ca}^{2+}$ (Joseph et al., 1989), which presumably reflects the effect of $\mathrm{pH}$ on binding of $\mathrm{IP}_{3}$ to its receptor.

The very high density of $\mathrm{IP}_{3}$ receptors present in the cerebellum facilitated purification of the receptor to apparent homogeneity (Supattapone et al., 1988b). The potent enhancement by heparin of $\mathrm{IP}_{3}$ binding to its receptor (Worley et al., 1987b) and of $\mathrm{Ca}^{2+}$ release (Hill et al., 1987; Ghosh et al., 1988; Guille- 
mette et al., 1989; Joseph and Rice, 1989) allowed the purification of the $\mathrm{IP}_{3}$ receptor on heparin-agarose affinity columns. A second purification step resorted to concanavalin-A Sepharose chromatography, which took advantage of the glycosylation of the $\mathrm{IP}_{3}$ receptor. Together, these purification steps allowed a thousandfold purification of the receptor. Meanwhile, the same degree of purification can be achieved also by use of an $\mathrm{IP}_{3}$ affinity column (Prestwich et al., 1991). When analyzed by PAGE, the purified $\mathrm{IP}_{3}$ receptor protein moved as a single $260 \mathrm{kDa}$ band. However, the molecular weight of the native receptor is about $1000 \mathrm{kDa}$, reflecting a homotetramer (Supattapone et al., 1988b) structure. This structure has been confirmed recently by chemical cross-linking studies (Maeda et al., 1991). The release of $\mathrm{Ca}^{2+}$ stimulation by $\mathrm{IP}_{3}$ may be positively cooperative (Meyer et al., 1988, 1990), suggesting that the four subunits interact such that activation of one subunit increases the probability that another subunit will be activated. However, ${ }^{3} \mathrm{H}-\mathrm{IP}_{3}$ binding to the pure receptor shows no evidence of cooperativity, with a Hill coefficient of approximately unity (Supattapone et al., 1988b).

The stimulation by $\mathrm{Ca}^{2+}$ of $\mathrm{IP}_{3}$ binding to its receptor largely disappears with purification of the receptor. In crude detergentsolubilized receptor preparations, as well as in intact membranes, $\mathrm{Ca}^{2+}$ in the 100-300 nM range inhibits $\mathrm{IP}_{3}$ binding, while $\mathrm{Ca}^{2+}$ has no influence on $\mathrm{IP}_{3}$ binding to the purified receptor protein at a thousandfold higher concentration (Supattapone et al., 1988b). Adding detergent-solubilized brain extracts to purified $\mathrm{IP}_{3}$ receptors restores the ability of $\mathrm{Ca}^{2+}$ to inhibit $\mathrm{IP}_{3}$ binding, indicating that a $\mathrm{Ca}^{2+}$-binding protein, designated calmedin, confers on $\mathrm{Ca}^{2+}$ the ability to influence $\mathrm{IP}_{3}$ binding (Danoff et al., 1988). Recently, calmedin has been isolated by taking advantage of its adhesion to the $\mathrm{IP}_{3}$ receptor so that under appropriate circumstances calmedin copurifies with the $\mathrm{IP}_{3}$ receptor on an $\mathrm{IP}_{3}$ affinity chromatography column (J. Steiner and S. H. Snyder, unpublished observations). Purified calmedin is a monomer with a molecular weight of about $15 \mathrm{kDa}$. In the presence of nanomolar concentrations of calmedin, $\mathrm{Ca}^{2+}$ substantially inhibits $\mathrm{IP}_{3}$ receptor binding. Calmedin levels in the brain do not parallel the high density of the $\mathrm{IP}_{3}$ receptor in cerebellum, suggesting that calmedin may influence other systems besides the $\mathrm{IP}_{3}$ receptor. Overall, calmedin comprises about $1 \%$ of membrane protein in the brain, similar to tissue levels of calmodulin.

$\mathrm{IP}_{3}$ receptors have also been purified to homogeneity from the aorta (Chadwick et al., 1990) and the vas deferens (Mourey et al., 1990) revealing properties closely similar to those of $\mathrm{IP}_{3}$ receptors in the brain (Marks et al., 1990). However, in the vas deferens $\mathrm{Ca}^{2+}$ does not inhibit $\mathrm{IP}_{3}$ binding to its receptor (Mourey et al., 1990), as it does not inhibit $\mathrm{IP}_{3}$ binding in neutrophils, liver cells, and adrenal membranes (Baukal et al., 1985; Spat et al., 1986; Guillemette et al., 1987). Experiments in which partially purified calmedin is mixed with purified $\mathrm{IP}_{3}$ receptors from cerebellar and vas deferens tissue indicate that the $\mathrm{IP}_{3}$ receptor of the vas deferens can respond to calmedin, so its lack of response to $\mathrm{Ca}^{2+}$ in situ reflects the absence of calmedin protein in that tissue (Mourey et al., 1990).

Purified $\mathrm{IP}_{3}$ receptors can be phosphorylated by cAMP-dependent protein kinase (PKA) (Supattapone et al., 1988a; Ferris et al., 1991b), PKC (Ferris et al., 1991b), and $\mathrm{Ca}^{2+} /$ calmodulindependent protein kinase (CAM-K-II) (Ferris et al., 1991b). Phosphorylation by any one of these enzymes proceeds stoichiometrically with one molecule of phosphate incorporated per receptor subunit. Phosphorylation by the three enzymes is additive, indicating that they act at different sites. Phosphopeptide maps and phosphoamino acid determination show that, while all thrce enzymes phosphorylate serine residues, they phosphorylate residues in different domains of the polypeptide chain (Ferris et al., 1991b). Isolation and direct sequencing of the peptides phosphorylated by PKA reveal that two serine residues, namely 1589 and 1755 , are phosphorylated (Ferris et al., 1991a). Serine 1755 is phosphorylated at low concentrations of PKA, while much higher concentrations of PKA are needed to phosphorylate serine 1589 .

We have found recently that $\mathrm{IP}_{3}$ receptors can autophosphorylate (Ferris et al., 1992a). This autophosphorylation is magnesium dependent and reaches a final stoichiometry of $0.3-$ $0.4 \mathrm{~mol}{ }^{32} \mathrm{P} / \mathrm{mol} \mathrm{IP}{ }_{3}$ receptor at $4^{\circ} \mathrm{C}$; possibly only a subpopulation of the receptors have this activity. Attribution of this phosphorylation to contaminating kinases is ruled out by several lines of evidence, including renaturation experiments in which autophosphorylation of the $260 \mathrm{kDa} \mathrm{IP}_{3}$ receptor is observed on nitrocellulose membranes following SDS-PAGE (Ferris et al., 1992a). Additionally, the $\mathrm{IP}_{3}$ receptor phosphorylates a synthetic peptide substrate, showing that the $\mathrm{IP}_{3}$ receptor possesses protein kinase activity.

How can phoshorylation of the $\mathrm{IP}_{3}$ receptor regulate its function? In cerebellar cell membranes, receptor phosphorylation by PKA decreases the potency of $\mathrm{IP}_{3}$ to release $\mathrm{Ca}^{2+}$ (Supattapone et al., 1988a). Since PKA phosphorylation also stimulates the $\mathrm{Ca}^{2+}$ pump, total ER $\mathrm{Ca}^{2+}$ levels are increased so that the absolute amount of $\mathrm{Ca}^{2+}$ released by $\mathrm{IP}_{3}$ is enhanced by PKA phosphorylation (Supattapone et al., 1988a). Recent studies indicate that cAMP-dependent hormones increase $\mathrm{IP}_{3}$-induced release of $\mathrm{Ca}^{2+}$ in liver cells (Burgess et al., 1991). It is conceivable that phosphorylation of the $\mathrm{IP}_{3}$ receptor by $\mathrm{PKC}$ and CAM-K-II provides feedback regulation of the PI cycle following the generation of DAG, which stimulates the action of PKC, and the release of $\mathrm{Ca}^{2+}$ by $\mathrm{IP}_{3}$, which can activate both PKC and Cam-K-II. A cerebellar-specific form of CAM-K-II is highly concentrated in Purkinje cells (Ouimet et al., 1984; Fukunaga et al., 1988; Walaas et al., 1988) and has a similar subcellular localization as the $\mathrm{IP}_{3}$ receptor.

The biological function of $\mathrm{IP}_{4}, \mathrm{IP}_{5}$, and $\mathrm{IP}_{6}$ has not yet been identified despite their levels in the brain being as high as those of $\mathrm{IP}_{3}$. Some studies suggest a role for $\mathrm{IP}_{4}$ in regulating the movement of $\mathrm{Ca}^{2+}$ into the cell and/or in maintaining levels of $\mathrm{IP}_{3}$-sensitive $\mathrm{Ca}^{2+}$ pools (Morris et al., 1987; Irvine, 1989; Cullen et al., 1990). $\mathrm{IP}_{5}$ and $\mathrm{IP}_{6}$ can increase $\mathrm{Ca}^{2+}$ accumulation (Nicoletti et al., 1989) and decrease blood pressure, heart rate (Vallejo et al., 1987; Barraco et al., 1989), and respiratory rate (Barraco et al., 1989). However, there is no evidence indicating whether any of these effects represent normal roles for these substances. Characterizing and localizing receptor proteins for these higher inositol phosphates might clarify their functions. $\mathrm{IP}_{4}$ binding sites have been identified in brain cell membranes (Theibert et al., 1987; Donie and Reiser, 1989), and IP $_{6}$ binding sites have also been characterized (Hawkins et al., 1990). Highaffinity $\mathrm{IP}_{4}$ - and $\mathrm{IP}_{6} / \mathrm{IP}_{5}$-binding proteins have recently been isolated from the brain (Theibert et al., 1991), which possess selectivity and high affinity for their respective ligands. The putative $\mathrm{IP}_{4}$ receptor binds $\mathrm{IP}_{4}$ with a $K_{D}$ of about $3 \mathrm{nM}$, while the putative $\mathrm{IP}_{6} / \mathrm{IP}_{5}$ receptor binds $\mathrm{IP}_{5}$ and $\mathrm{IP}_{6}$ with a $K_{D}$ of about 6-12 nM. The putative $\mathrm{IP}_{5} / \mathrm{IP}_{6}$ receptor comprises two 115 and $105 \mathrm{kDa}$ doublets and a $50 \mathrm{kDa}$ singlet. Tryptic peptides 
from the $105 \mathrm{kDa}$ doublet have been sequenced recently, revealing that the $\mathrm{IP}_{6}$ receptor complex is identical to the clathrinassociated assembly protein AP-2 (A. B. Theibert, S. Voglmaier, C. D. Ferris, J. Keen, and S. H. Snyder, unpublished observations). Three prominent $\mathrm{IP}_{4}$ receptor subunits of molecular weight about 182,174 , and $84 \mathrm{kDa}$ can be distinguished. Another IP. receptor protein has been isolated independently with similar properties except that it is of lower molecular weight (Donie and Reiser, 1991). This difference may reflect proteolytic cleavage of the latter isolate. To ascertain which subunits of the IP. and $\mathrm{IP}_{5} / \mathrm{IP}_{6}$ receptor proteins carry recognition sites for their ligands, a radiolabeled photoaffinity ligand was employed, permitting analysis of the $\mathrm{pH}$ dependence and other properties of these proteins and their subunits (Theibert et al., 1992). The inositol phosphate binding specificity, $\mathrm{pH}$ dependence, and influence of $\mathrm{Ca}^{2+}$ were found to be identical for the 105 and 115 $\mathrm{kDa} \mathrm{IP}_{6}$ proteins. By contrast, the $\mathrm{IP}_{4}$ receptor subunits differ in various respects. The $\mathrm{pH}$ dependence for ligand binding by the 174 and $182 \mathrm{kDa}$ proteins is similar, with an optimum at about $\mathrm{pH} 7$, while the $85 \mathrm{kDa}$ protein displays substantial binding at lower $\mathrm{pH}$ levels, similar to the $\mathrm{IP}_{4}$ receptor protein isolated by Donie and Reiser (1991). $\mathrm{Ca}^{2+}$ markedly enhances $\mathrm{IP}_{4}$ binding to the 182 and $174 \mathrm{kDa}$ proteins, unlike the marked $\mathrm{Ca}^{2+}$ stimulation of binding observed for the $84 \mathrm{kDa}$ protein.

\section{Reconstitution of $\mathrm{IP}_{3}$-activated $\mathrm{Ca}^{2+}$ channels and their regulation}

Does the $\mathrm{IP}_{3}$-binding protein also contain the $\mathrm{Ca}^{2+}$ channel that responds to $\mathrm{IP}_{3}$, or is the $\mathrm{Ca}^{2+}$ channel a distinct protein? To address this question, experiments were carried out in lipid vesicles containing only $\mathrm{IP}_{3}$ receptor protein in the reconstituted membrane. This permitted measurement of the $\mathrm{IP}_{3}$ influence on ${ }^{45} \mathrm{Ca}^{2+}$ release as well as ${ }^{3} \mathrm{H}-\mathrm{IP}_{3}$ binding in the same vesicles. In such vesicles, $\mathrm{IP}_{3}$ was found to stimulate $\mathrm{Ca}^{2+}$ release (Ferris et al., 1989). The relative potencies of $\mathrm{IP}_{3}$ and other inositol phosphates to influence $\mathrm{Ca}^{2+}$ release correspond closely with their affinities for $\mathrm{IP}_{3}$ binding sites. Moreover, heparin, a known $\mathrm{IP}_{3}$ antagonist, blocks the actions of $\mathrm{IP}_{3}$ on $\mathrm{Ca}^{2+}$ release in the reconstituted system. These experiments established that the purified $\mathrm{IP}_{3}$-binding protein contains both the $\mathrm{IP}_{3}$ recognition site and the $\mathrm{Ca}^{2+}$ channel (Ferris et al., 1989).

Use of reconstituted vesicles containing $\mathrm{IP}_{3}$ receptors has permitted demonstration of an allosteric regulation of the receptor by adenine nucleotides (Ferris et al., 1990). At concentrations between 1 and $10 \mu \mathrm{M}$, ATP markedly and cooperatively enhances the ability of $\mathrm{IP}_{3}$ to stimulate $\mathrm{Ca}^{2+}$ release. This effect is biphasic, since the enhancing effects on $\mathrm{IP}_{3}$-stimulated $\mathrm{Ca}^{2+}$ release diminish between 0.1 and $1 \mathrm{~mm}$ until, at the physiological concentration of $1 \mathrm{mM}$, ATP no longer enhances $\mathrm{IP}_{3}$-stimulated $\mathrm{Ca}^{2+}$ release at all. This enhancement by ATP is readily distinguished from phosphorylation by use of nonhydrolyzable ATP analogs and is specific for ATP, in comparison with other adenine or guanine nucleotides. It is mediated via a high-affinity ATP recognition site on the $\mathrm{IP}_{3}$ receptor, which can be labeled by its binding of ${ }^{32} \mathrm{P}-\mathrm{ATP}$ or ${ }^{35} \mathrm{~S}-\mathrm{ADP}-\beta$-S (Ferris et al., 1990) or by its reaction with an azido derivative of ATP (Maeda et al., 1991). The predicted amino acid sequence of the cerebellar $\mathrm{IP}_{3}$ receptor contains two possible consensus sequences (GXGXXG) for ATP binding at amino acid residues 1773 and 2016 (Furuichi et al., 1989).

How might ATP influence the action of $\mathrm{IP}_{3}$ ? At physiological concentrations (about $1 \mathrm{mM}$ ) of ATP, one would expect no obvious influence. However, once $\mathrm{IP}_{3}$ stimulates $\mathrm{Ca}^{2+}$ release, the $\mathrm{Ca}^{2+}$-dependent ATPase would be activated to replenish the $\mathrm{Ca}^{2+}$ stores, which can deplete ATP in the vicinity of the $\mathrm{IP}_{3}$ receptor. ATP bound with low affinity will then dissociate, and $\mathrm{IP}_{3}$-stimulated $\mathrm{Ca}^{2+}$ release would be augmented in feedforward manner. If ATP levels fall even further, then the ATP bound with high affinity would dissociate, and $\mathrm{IP}_{3}$-stimulated release of $\mathrm{Ca}^{2+}$ would diminish, perhaps protecting the cells from noxious $\mathrm{Ca}^{2+}$ concentrations. This model might contribute to the precipitous, spikelike changes in intracellular $\mathrm{Ca}^{2+}$ concentrations associated with $\mathrm{Ca}^{2+}$ oscillations (Smith et al., 1986; Berridge, 1990; Petersen and Wakui, 1990; Meyer and Stryer, 1991) and help account for the marked cooperativity of $\mathrm{IP}_{3}$-induced $\mathrm{Ca}^{2+}$ release (Meyer et al., 1988, 1990). A similar augmentation of $\mathrm{Ca}^{2+}$ release induced by ATP in reconstituted $\mathrm{IP}_{3}$ receptors in planar lipid bilayers has been reported (Maeda et al., 1991). ATP also enhances $\mathrm{IP}_{3}$ stimulation of $\mathrm{Ca}^{2+}$ channels in crude preparations of ER from the aorta (Ferris et al., 1989) and permeabilized cells (Smith et al., 1985).

In permeabilized pancreatic acinar cells, $\mathrm{IP}_{3}$-stimulated $\mathrm{Ca}^{2+}$ release is a noncontinuous process, such that submaximal concentrations of $\mathrm{IP}_{3}$ release submaximal portions of $\mathrm{IP}_{3}$-sensitive $\mathrm{Ca}^{2+}$ stores (Muallem et al., 1989) even under conditions where the $\mathrm{IP}_{3}$ is not degraded. This process was described as "quantal" since subfractions of $\mathrm{IP}_{3}$-sensitive $\mathrm{Ca}^{2+}$ stores are activated by $\mathrm{IP}_{3}$. In permeabilized basophils, Meyer and Stryer (1990) described the same phenomenon as "incremental" release. Sequential additions of $\mathrm{IP}_{3}$ evoke a transient release of $\mathrm{Ca}^{2+}$, monitored with $\mathrm{Ca}^{2+}$-sensitive dyes, such that the final free $\mathrm{Ca}^{2+}$ level for two sequential $\mathrm{IP}_{3}$ applications is the same as a single application of the sum (Meyer and Stryer, 1990). Incremental stimulation of $\mathrm{Ca}^{2+}$ release by $\mathrm{IP}_{3}$ could be attributable to many factors. The quantal $\mathrm{Ca}^{2+}$ release in purified, reconstituted $\mathrm{IP}_{3}$ receptors indicates that the phenomenon is a fundamental property of the $\mathrm{IP}_{3}$ receptor (Ferris et al., 1992b). Submaximal concentrations of $\mathrm{IP}_{3}$ fail to activate all of the $\mathrm{Ca}^{2+}$ channels in the reconstituted system (Ferris et al., 1992b). Moreover, successive additions of $\mathrm{IP}_{3}$ provide an arithmetic increase in $\mathrm{Ca}^{2+}$ release over the range of 10-200 nм IP (Fig. 1) (Ferris et al., 1992b). Since $\mathrm{Ca}^{2+}$ signaling in cells is known to be spatially and temporally complex (Alkon and Rasmussen, 1988), involving $\mathrm{Ca}^{2+}$ oscillations and waves (Berridge, 1990; Meyer and Stryer, 1991), it is likely that the sequential release properties of the $\mathrm{IP}_{3}$ receptor are critical for this precise subcellular regulation of $\mathrm{Ca}^{2+}$ levels in cells.

\section{Molecularly cloned $I P_{3}$ receptors in multiple forms}

The first cloning of the $\mathrm{IP}_{3}$ receptor gene arose from efforts to characterize a cerebellar-specific protein designated P-400 (Furuichi et al., 1989), originally identified as a $400 \mathrm{kDa}$ cerebellar protein localized to Purkinje cells (Mallet et al., 1976). The characteristics of P-400 (Mikoshiba and Changeux, 1978; Mikoshiba et al., 1979; Maeda et al., 1990) were recognized to be those of the previously isolated $\mathrm{IP}_{3}$ receptor (Supattapone et al., $1988 \mathrm{~b}$ ). Based on the partial sequence of the cDNA of a Purkinje cell-specific protein (Nordquist et al., 1988) antibodies were raised, and resultant immunohistochemical maps revealed that the protein encoded in the cloned $\mathrm{P}-400$ gene was the $\mathrm{IP}_{3}$ receptor (Mignery et al., 1989, 1990). The human $\mathrm{IP}_{3}$ receptor was cloned and sequenced from brain libraries (Ross et al., 1991). Comprising more than 2700 amino acid residues, the IP ${ }_{3}$ receptor is one of the largest proteins to have been cloned and 
Figure 1. Incremental activation of $\mathrm{IP}_{3}$ channels in reconstituted $\mathrm{IP}_{3}$ receptor by successive additions of $I_{3} . I_{3}$-induced ${ }^{45} \mathrm{Ca}^{2+}$ release was measured as previously described (Ferris et al., 1989). In this preparation, $\mathrm{IP}_{3}$ activates $\mathrm{Ca}^{2+}$ channels, which allows the rapid equilibration of ${ }^{45} \mathrm{Ca}^{2+}$ into vesicles with activated channels in the absence of an actual $\mathrm{Ca}^{2+}$ concentration gradient. Specific cpm refers to the difference between the presence and absence of $\mathrm{IP}_{3}$. $\Lambda$ ddition of $50 \mathrm{nM} \mathrm{IP}_{3}$ to vesicles following $10 \mathrm{sec}$ incubation with $50 \mathrm{~nm}$ $\mathrm{IP}_{3}$ results in enhanced ${ }^{45} \mathrm{Ca}^{2+}$ entry to the same level as an initial addition of $100 \mathrm{~nm} \mathrm{IP}_{3}$. Likewise, successive $10 \mathrm{sec}$ incubations with final $\mathrm{IP}_{3}$ concentrations of $50 \mathrm{nM}, 100 \mathrm{nM}$, and $200 \mathrm{nM}$ result in quantitative detection of changes in $\mathrm{IP}_{3}$ concentration. Thus, unlike other known ligand activated ion channels which either desensitize (e.g., the nicotinic $\mathrm{ACh}$ receptor) or allow continuous ion transport, the $\mathrm{IP}_{3}$ receptor exhibits quantal release properties. Adapted from Ferris et al. (1992b).

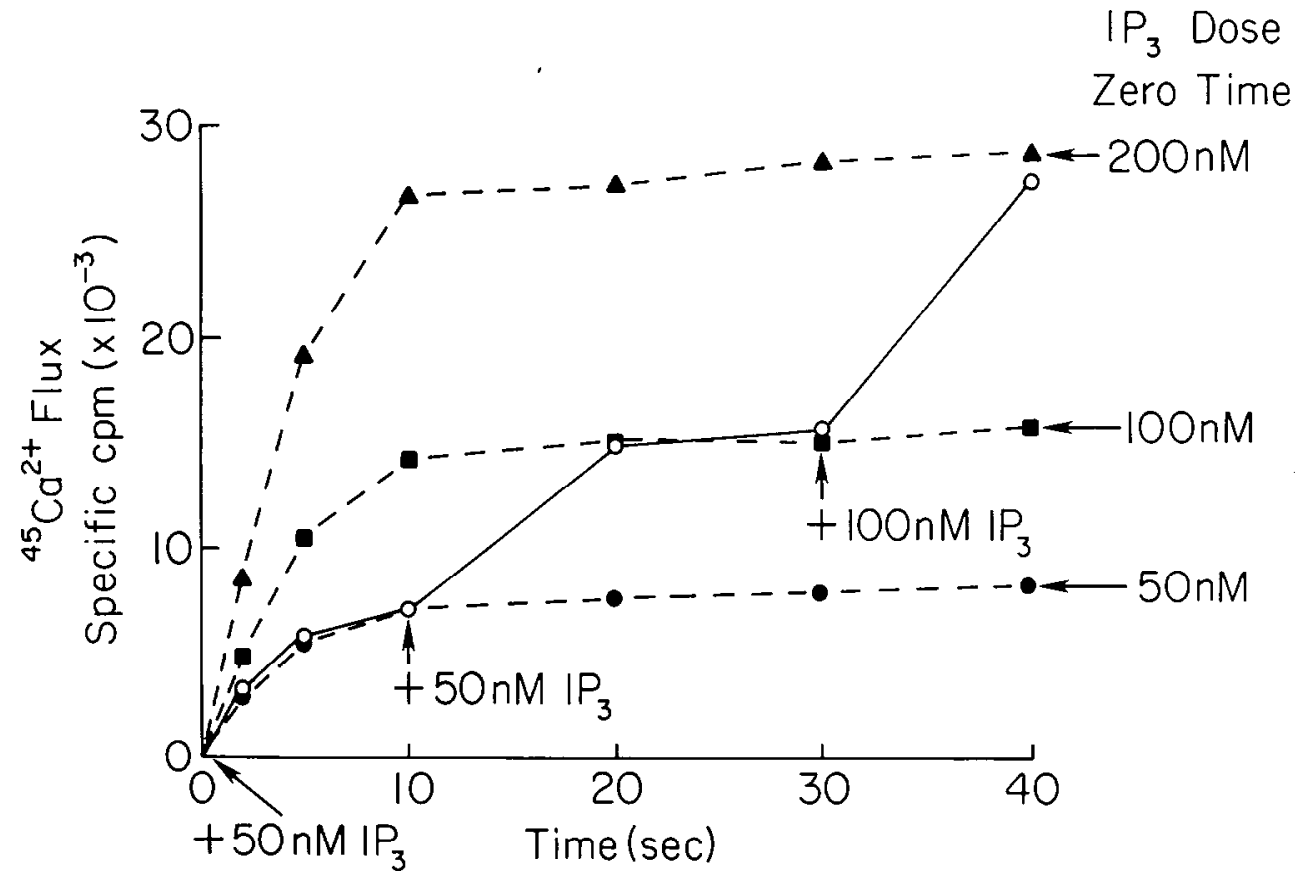

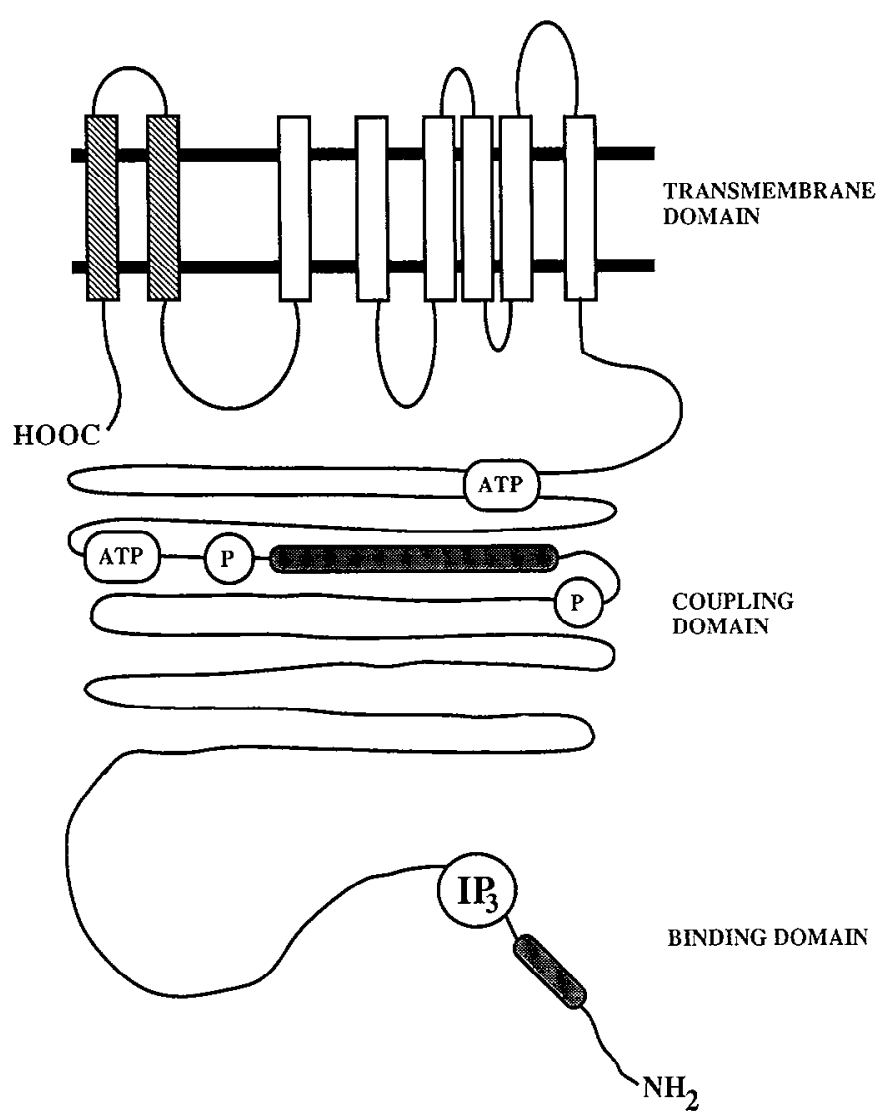

Figure 2. Topology of the $\mathrm{IP}_{3}$ receptor. The $\mathrm{IP}_{3}$ reccptor is a large transmembrane protein with eight hydrophobic putative transmembrane domains at the carboxyl terminus (hatched), a domain of 300400 amino acid residues at the amino terminus that are sufficient for minimal ligand binding (Mignery and Sudhof, 1990), and a large hydrophobic and cytosolic coupling domain between which are regulatory sites for phosphorylation, ATP binding, and alternative splicing in the mRNA. In the binding and coupling domains, known alternative splicing sites are shaded. The putative sites for ligand $\left(I P_{3}\right.$ and $\left.A T P\right)$ binding are labeled, as are sites known to be phosphorylated by PKA $(P$; Ferris et al., 1991a). The sites phosphorylated by PKC and CAM-K-II (Ferris et al., 1991b) are not yet known. sequenced. It is highly conserved among the mammals, as the sequences in rodents and humans differ by less than $10 \%$ and only by $1 \%$ in rat and mousc.

Several very similar molecular models for the $\mathrm{IP}_{3}$ receptor have been suggested. A consensual model (Fig. 2) of an individual subunit comprises eight transmembrane domains located at the carboxy terminus of the molecule, with both the amino and carboxy termini on the cytoplasmic surface. Among the eight transmembrane domains, the first four are flanked by net positive charges and the last four by net negative charges (Mignery and Sudhof, 1990). The last four transmembrane domains show the closest homology with the ryanodine receptor (Furuichi et al., 1989; Mignery et al., 1989, 1990), the $\mathrm{Ca}^{2+}$-stimulated $\mathrm{Ca}^{2+}$ release channel of muscle, and so are likely to comprise the $\mathrm{Ca}^{2+}$-permeable pore.

Mutagenesis studies suggest that the $\mathrm{IP}_{3}$ binding site lies in the amino-terminal 400 amino acid residue since receptors with this domain deleted fail to bind $\mathrm{IP}_{3}$ (Mignery and Sudhof, 1990; Miyawaki et al., 1991). Moreover, truncated forms of the receptor retaining only the $\mathrm{N}$-terminal quarter of the molecule provide soluble peptides that are monomeric but retain $\mathrm{IP}_{3}$ binding capacity (Mignery and Sudhof, 1990; Miyawaki et al., 1991). The $\mathrm{N}$-terminal peptide binds $\mathrm{IP}_{3}$ with substantially less affinity than does the full protein, so the overall conformation of the intact protein may be important for physiologic $\mathrm{IP}_{3}$ binding. Because the $\mathrm{IP}_{3}$ binding site is at the extreme $\mathrm{N}$-terminal part of the protein, with the putative $\mathrm{Ca}^{2+}$ channel at the extreme $\mathrm{C}$-terminal, $\mathrm{IP}_{3}$ binding must clicit a conformational changc over a span of virtually 1400 amino acid residues. This fits with findings that a substantial decrease in apparent molecular weight on gel filtration occurs consequent to $\mathrm{IP}_{3}$ binding (Mignery and Sudhof, 1990). Both sites at which PKA catalyzes serine phosphorylation (Ferris et al., 1991a), as well as the ATP consensus binding sites (Ferris and Snyder, 1991), are located in the "coupling region" between domains for $\mathrm{IP}_{3}$ binding and the $\mathrm{Ca}^{2+}$ channel, where these regulatory sites may affect the ability of $\mathrm{IP}_{3}$ binding to activate the $\mathrm{Ca}^{2+}$ channel. 
The evolutionary conservation of the primary structure of the $\mathrm{IP}_{3}$ receptor suggests that there might be only a single type of $\mathrm{IP}_{3}$ receptor. However, multiple forms of $\mathrm{IP}_{3}$ receptors derived by alternative mRNA splicing have been observed (Mignery et al., 1990; Danoff et al., 1991; Nakagawa et al., 1991). One of these forms has been found in rats and mice, with a deletion of 15 amino acids close to the N-terminus (Mignery et al., 1990; Nakagawa et al., 1991). Alternatively spliced forms with a deletion of 40 amino acids in the $\mathrm{N}$-terminal third of the molecule, but not as close to the $\mathrm{N}$-terminus as the 15 amino acid deletion, have also been observed (Danoff et al., 1991; Nakagawa et al., 1991). Several forms of the receptor with different portions of the 40 amino acid sequence deleted have been detected, suggesting that the 40 amino acids derive from two separate exons (Nakagawa et al., 1991). By use of the PCR to monitor relative levels of the receptor with and without the 40 amino acid deletion, it was observed that the long form is exclusively neuronal while the short form appears to be predominantly in non-neuronal tissues (Danoff et al., 1991), although the "non-neuronal" form has also been detected in the spinal cord (Nakagawa ct al., 1991). Substantial differences in levels of the alternatively spliced form of the receptor occur throughout the brain (Nakagawa et al., 1991) For instance, the form with the 15 amino acid deletion accounts for $75-85 \%$ of $\mathrm{IP}_{3}$ receptors in the spinal cord and cerebellum but only for $12 \%$ of receptors in the cerebral cortex. The proportion of receptors with different extents of loss of the 40 amino acid sequence varies substantially in mouse brain regions as well (Nakagawa et al., 1991). While all peripheral tissues lack the 40 amino acid sequence, the presence or absence of the 15 amino acid sequence varies substantially among different peripheral organs.

The 40 amino acids deleted in the non-neuronal form lie between two serines at positions 1589 and 1756, which are phosphorylated by PKA (Ferris et al., 1991a). To examine the influence of the deletion upon phosphorylation, we compared phosphorylation by PKA of the neuronal (cerebellum) and nonneuronal (vas deferens) receptors. While both are stoichiometrically phosphorylated by PKA, the pattern of phosphorylation differs. The brain receptor is preferentially phosphorylated on serine 1756, while the vas deferens receptor is phosphorylated on serine 1589. The 40 amino acid sequence also lies in the area of two consensus sequences for ATP binding, and removal of the 40 amino acid sequence creates a new consensus sequence for ATP binding (Ferris and Snyder, 1991).

Evidence has recently been obtained for the existence of other members of the $\mathrm{IP}_{3}$ receptor family derived from distinct genes (Ross et al., 1991; Sudhof et al., 1991). These other putative members of the $\mathrm{IP}_{3}$ receptor group are less abundant in brain than the "parent" $\mathrm{IP}_{3}$ receptor, and their functions are unclear. The most striking "cousin" of the $\mathrm{IP}_{3}$ receptor is the ryanodine receptor (Furuichi et al., 1989; Mignery et al., 1989; Takeshima et al., 1989). Ryanodine is an alkaloid that binds to a protein that is responsible for $\mathrm{Ca}^{2+}$-induced $\mathrm{Ca}^{2+}$ release (CICR) from the sarcoplasmic reticulum of striated muscle as a key component of excitation-contraction coupling(Endo, 1977; Fleischer and Inui, 1989). Thus, both $\mathrm{IP}_{3}$ and ryanodine receptors have $\mathrm{Ca}^{2+}$ channels to promote release of intracellular $\mathrm{Ca}^{2+}$, with the ligand for one being $\mathrm{IP}_{3}$ and for the other being $\mathrm{Ca}^{2+}$ itself. Ryanodinc and $\mathrm{IP}_{3}$ receptors are both large homotctramcric proteins that, when examined under the electron microscope, display fourfold symmetry, with the $\mathrm{IP}_{3}$ receptor having forms that appear more mobile than the ryanodine receptor. ATP directly induces $\mathrm{Ca}^{2+}$ release at the ryanodine receptor, whereas at the $\mathrm{IP}_{3}$ receptor, ATP enhances the stimulation of $\mathrm{Ca}^{2+}$ release by $\mathrm{IP}_{3}$. While $\mathrm{IP}_{3}$ receptors are concentrated in the brain and smooth muscle, ryanodine receptors are at their highest levels in skeletal and cardiac muscle, with much lower levels in smooth muscle and brain. A limited capacity to bind ${ }^{3} \mathrm{H}$-ryanodine in the brain has been reported (McPherson and Campbell, 1990), and high-resolution immunohistochemistry has revealed both ryanodine and $\mathrm{IP}_{3}$ receptors within the same Purkinje cells in the cerebellum (Ellisman et al., 1990).

\section{Localization of $\mathrm{IP}_{3}$ and ryanodine receptors in the brain in relation to $\mathrm{Ca}^{2+}$ pools}

$\mathrm{IP}_{3}$ receptors have been localized by autoradiography (Worley et al., 1987a, 1989) and immunohistochemistry (Ross et al., 1989), and their mRNA has been detected by in situ hybridization with cloned DNA probes (C. A. Ross, C. Glatt, T. Dawson, and $\mathrm{S}$. H. Snyder, unpublished observations). $\mathrm{IP}_{3}$ receptors are at their highest density in Purkinje cells of the cerebellum and at their second highest density in the hippocampus, espccially in the CA1 region. Receptors have been observed throughout the processes of neurons, with substantial densities being present in terminals of Purkinje cells in the deep nuclei of the cerebellum. In the retina, $\mathrm{IP}_{3}$ receptors are at high density in presynaptic nerve terminals of photoreceptors and bipolar cells, as well as in synaptic specializations of amacrine cells (Peng et al., 1991). The association of these receptors with nerve terminals may reflect a role for them in neurotransmitter release, perhaps modulating the influx of $\mathrm{Ca}^{2+}$ through voltage-gated channels that trigger exocytosis of synaptic vesicles. The first studies of $\mathrm{IP}_{3}$-stimulated release of $\mathrm{Ca}^{2+}$ indicated a nonmitochondrial source, which might reflect ER (Streb et al., 1983). Electron microscopic immunohistochemistry (Mignery et al., 1989; Ross et al., 1989; Otsu et al., 1990; Satoh et al., 1990) confirms an association of $\mathrm{IP}_{3}$ receptors with subcomponents of the ER. Both rough and smooth ER are labeled, but with considerably hetcrogencous distribution: some elements that show high densities of the receptor label may lie adjacent to morphologically similar but unlabeled elements. In some studies on Purkinje cells, substantial densities of receptor were evident in the ER close to the nuclear membrane and in the nuclear membrane itself (Ross et al., 1989; Satoh et al., 1990). A role for $\mathrm{IP}_{3}$ in nuclear function is further strengthened by observations of nuclear ATP-dependent $\mathrm{Ca}^{2+}$ uptake (Nicotera et al., 1989), $\mathrm{IP}_{3}$-stimulated release of $\mathrm{Ca}^{2+}$ (Malviya et al., 1990; $\mathrm{Ni}$ cotera et al., 1990), as well as $\mathrm{IP}_{3}$ binding (Malviya et al., 1990) in liver nuclei. Cocco et al. (1987) reported polyphosphoinositide synthesis in nuclei of erythroleukemia cells with changes during differentiation.

Immunohistochemical studies of $\mathrm{IP}_{3}$ localization in Purkinje cells in cerebellum have failed to detect its presence in mitochondria, Golgi cisternae, or the plasma membrane. However, $\mathrm{IP}_{3}$-activated $\mathrm{Ca}^{2+}$ channels may be present in plasma membranes of lymphocytes (Kuno and Gardner, 1987). $\mathrm{IP}_{3}$ activation of dihydropyridine-sensitive $\mathrm{Ca}^{2+}$ channels has also been detected in preparations of skeletal muscle transverse tubules, which presumably represent plasma membrane channels (Vilven and Coronado, 1988). Direct evidence has recently been obtained for the existence of $\mathrm{IP}_{3}$ receptors in the plasma membrane of olfactory cilia and lymphocytes. Immunohistochemical studies resorting to confocal microscopy reveal a selective association of $\mathrm{IP}_{3}$ receptors with olfactory cilia, which lack ER (A. Cunningham, G. Ronnett, R. Reed, and S. H. Snyder, unpublished observations). Moreover, $\mathrm{IP}_{3}$ receptors are selectively localized 
in the plasma membrane of intact Jurkat $\mathrm{T}$ lymphocytes under conditions in which the antibody does not penetrate into cells (A. Khan, J. Steiner, and S. H. Snyder, unpublished observations). Moreover, in these cells capping induced by concanavalin $A$ is associated with a concentration of $\mathrm{IP}_{3}$ receptor at one pole of the cell, a bchavior manifested only by plasma membrane proteins.

$\mathrm{IP}_{3}$ receptors in brain slices colocalize with $\mathrm{IP}_{3}$-sensitive $\mathrm{Ca}^{2+}$ pools in the ER labeled with ${ }^{45} \mathrm{Ca}^{2+}$ in the presence of ATP (Verma et al., 1990). The ER stores of $\mathrm{Ca}^{2+}$ labeled in this way display discrete localizations. $\mathrm{IP}_{3}$ can stimulate the release of most of the $\mathrm{Ca}^{2+}$ from some brain regions, while other brain regions are relatively resistant to the effects of $\mathrm{IP}_{3}$. Recently, it has been possible to identify $\mathrm{Ca}^{2+}$-sensitive $\mathrm{Ca}^{2+}$ stores in these preparations (A. Verma, Hirsch, and S. H. Snyder, unpublished observations). In both brain ER and slices, $\mathrm{Ca}^{2+}$ accumulation increases with increasing concentrations of added $\mathrm{Ca}^{2+}$, but then begins to decrease. The decline in accumulated $\mathrm{Ca}^{2+}$ reflects CICR, since the decline is prevented by local anesthetics such as tetracaine and $\mathrm{Mg}^{2+}$, which block CICR. Moreover, this decline is accentuated by caffeine and ATP, which enhance CICR. $\mathrm{Ca}^{2+}$ release stimulated by $\mathrm{IP}_{3}$ occurs at lower free $\mathrm{Ca}^{2+}$ concentrations than the CICR process. Thus, as $\mathrm{IP}_{3}$ induces release of $\mathrm{Ca}^{2+}$ to provide concentrations greater than $0.5 \mu \mathrm{M}$, the released $\mathrm{Ca}^{2+}$ inhibits further actions of $\mathrm{IP}_{3}$ and also triggers initiation of the CICR process. The coordinated effects of $\mathrm{IP}_{3}$ and CICR on $\mathrm{Ca}^{2+}$ release provide an enhancement of $\mathrm{Ca}^{2+}$ release that may influence $\mathrm{Ca}^{2+}$ oscillations.

IP $_{3}$-sensitive and CICR pools of $\mathrm{Ca}^{3+}$ arc differentially localized. For instance, in the hippocampus CAl is enriched in the $\mathrm{IP}_{3}$ pool, while CA 3 has higher densities of CICR. The corpus striatum is enriched in $\mathrm{IP}_{3}$-stimulated $\mathrm{Ca}^{2+}$ channels, while the closely adjacent medial septum has higher densities of CICR. Cerebellar Purkinje cells are greatly enriched in the $\mathrm{IP}_{3}$ pool, while the CICR pool predominates in the olfactory bulb. It will be a challenging task to differentiate physiological functions associated with $\mathrm{IP}_{3}$ and CICR, respectively.

\section{References}

Alkon DL, Rasmussen H (1988) A spatial-temporal model of cell activation. Science 239:998-1005.

Barraco RA, Phillis JW, Simpson LL (1989) Cardiorcspiratory cffects of inositol hexakisphosphate following microinjections into the nucleus tractus solitarii. Eur J Pharmacol 173:75-84.

Baukal AJ, Guillemette G, Rubin R, Spat A, Catt KJ (1985) Binding sites for inositol trisphosphate in the bovine adrenal cortex. Biochem Biophys Res Commun 133:532-538.

Berridge MJ (1987) Inositol trisphosphate and diacylglycerol: two interacting second messengers. Annu Rev Biochem 56:159-193.

Berridge MJ (1990) Calcium oscillations. J Biol Chem 265:9583-9586.

Berridge MJ, Irvine RF (1989) Inositol phosphates and cell signalling. Nature 341:197-204.

Berridge MJ, Downes CP, Hanley MR (1982) Lithium amplifies agonist-dependent phosphatidylinositol responses in brain and salivary glands. Biochem J 206:587-595.

Bredt DS, Mourey RJ, Snyder SH (1989) A simplc, sensitive and specific radioreceptor assay for inositol 1,4,5-trisphosphate in biological tissues. Biochem Biophys Res Commun 159:976-982.

Burgess GM, Bird GSJ, Obie JF, Putney JW Jr (1991) The mechanism for synergism between phospholipase C- and adenylylcyclase-linked hormones in liver. J Biol Chem 266:4772-4781.

Chadwick CC, Saito A, Fleischer S (1990) Isolation and characterization of the inositol trisphosphate receptor from smooth muscle. Proc Natl Acad Sci USA 87:2132-2136.

Challiss RA, Nahorski SR (1990) Neurotransmitter and depolariza- tion-stimulated accumulation of inositol 1,3,4,5-tetrakisphosphate mass in rat cerebral cortex slices. J Neurochem 54:2138-2141.

Challiss RA, Chilvers ER, Willcocks AL, Nahorski SR (1990) Heterogeneity of $\left[{ }^{3} \mathrm{H}\right]$ inositol 1,4,5-trisphosphate binding sites in adrenalcortical membranes. Characterization and validation of a radioreceptor assay. Biochem J 265:421-427.

Cocco L, Gilmour RS, Ognibene A, Letcher AJ, Manzoli FA, Irvine RF (1987) Synthesis of polyphosphoinositides in nuclei of Friend cells. Biochem J 248:765-770.

Cullen PJ, Irvine RF, Dawson AP (1990) Syncrgistic control of $\mathrm{Ca}^{2+}$ mobilization in permeabilized mouse L 1210 lymphoma cells by inositol 2,4,5-trisphosphate and inositol 1,3,4,5-tetrakisphosphate. Biochem J 271:549-553.

Danoff SK, Supattapone S, Snyder SH (1988) Characterization of a membrane protein from brain mediating the inhibition of inositol 1,4,5-trisphosphate receptor binding by calcium. Biochem J 254:701705.

Danoff SK, Ferris CD, Donath C, Fischer G, Munemitsu S, Ullrich A Snyder SH, Ross CA (1991) Inositol 1,4,5-trisphosphate receptors: distinct neuronal and non-neuronal forms derived by alternative splicing differ in phosphorylation. Proc Natl Acad Sci USA 88:29512955.

Donie F, Reiser G (1989) A novel specific binding protein assay for quantitation of intracellular inositol 1,3,4,5-tetrakisphosphate (InsP4) using a high-affinity InsP4 receptor from cerebellum. FEBS Lett 254 $155-158$

Donie F, Reiser G (1991) Purification of a high-affinity inositol 1,3,4,5tetrakisphosphate receptor from brain. Biochem J 275:453-457.

Ellisman MH, Deerinck TJ, Ouyang Y, Beck CF, Tanksley SJ, Walton PD, Airey JA, Sutko JL (1990) Identification and localization of ryanodine binding proteins in the avian central nervous system. Neuron 5:135-146.

Endo M (1977) Calcium release from the sarcoplasmic reticulum. Physiol Rev 57:71-108.

Ferris CD, Snyder SH (1992) Inositol 1,4,5-trisphosphate activated calcium channels. Annu Rev Physiol 54:469-488.

Ferris CD, Huganir RL, Supattapone S, Snyder SH (1989) Purified inositol 1,4,5-trisphosphate receptor mediates calcium flux in reconstituted lipid vesicles. Nature 342:87-89.

Ferris CD, Huganir RL, Snyder SH (1990) Calcium flux mediated by purified inositol 1,4,5-trisphosphate receptor in reconstituted lipid vesicles is allosterically regulated by adenine nucleotides. Proc Natl Acad Sci USA 87:2147-2151.

Ferris CD, Cameron AM, Bredt DS, Huganir RL, Snyder SH (1991a) Inositol 1,4,5-trisphosphate receptor is phosphorylated by cyclic AMPdependent protein kinase at serines 1755 and 1589. Biochem Biophys Res Commun 175:192-198.

Ferris CD, Huganir RL, Bredt DS, Cameron AM, Snyder SH (1991b) Inositol trisphosphate receptor: phosphorylation by protein kinase $C$ and calcium-calmodulin dependent protein kinases in reconstituted lipid vesicles. Proc Natl Acad Sci USA 88:2232-2235.

Ferris CD, Camcron AM, Bredt DS, Huganir RL, Snyder SH (1992a) Autophosphorylation of inositol 1,4,5-trisphosphate receptors. J Biol Chem, in press.

Ferris CD, Cameron AM, Huganir RL, Snyder SH (1992b) Quantal calcium release by purified reconstituted inositol 1,4,5-trisphosphate receptors. Nature, in press.

Fleischer S, Inui M (1989) Biochemistry and biophysics of excitationcontraction coupling. Annu Rev Biophys Biophys Chem 18:333-364.

Fukunaga K, Goto S, Miyamoto E (1988) Immunohistochemical localization of $\mathrm{Ca}^{2+} /$ calmodulin-dependent protein kinase II in rat brain and various tissues. J Neurochem 51:1070-1078.

Furuichi T, Yoshikawa S, Miyawaki A, Wada K, Maeda N, Mikoshiba K (1989) Primary structure and functional expression of the inositol 1,4,5-trisphosphate-binding protein P400. Nature 342:32-38.

Ghosh TK, Eis PS, Mullaney JM, Ebert CL, Gill DL (1988) Competitive, reversible, and potent antagonism of inositol 1,4,5-trisphosphate-activated calcium release by heparin. J Biol Chem 263: $11075-11079$.

Godfrey PP (1989) Potentiation by lithium of CMP-phosphatidate formation in carbachol-stimulated rat cerebral-cortical slices and its reversal by myo-inositol. Biochem J 258:621-624.

Guillemette G, Balla T, Baukal AJ, Spat A, Catt KJ (1987) Intracellular receptors for inositol 1,4,5-trisphosphate in angiotensin II target tissues. J Biol Chem 262:1010-1015. 
Guillemette G, Lamontagne S, Boulay G, Mouillac B (1989) Differential effects of heparin on inositol 1,4,5-trisphosphate binding, metabolism, and calcium release activity in the bovine adrenal cortex. Mol Pharmacol 35:339-344.

Hawkins PT, Reynolds DJ, Poyner DR, Hanley MR (1990) Identification of a novel inositol phosphate recognition site: specific $\left.{ }^{3} \mathrm{H}\right]$ inositol hexakisphosphate binding to brain regions and cerebellar membranes. Biochem Biophys Res Commun 167:819-827.

Hill TD, Berggren P-O, Boynton AL (1987) Heparin inhibits inositol trisphosphate-induced calcium release from permcabilized rat liver cells. Biochem Biophys Res Commun 149:897-901.

Hwang PM, Bredt DS, Snyder SH (1990) Autoradiographic imaging of phosphoinositide turnover in the brain imaging in the brain. Science 249:802-804.

Irvine R (1989) Functions of inositol phosphates. In: Inositol lipids in cell signalling, pp 135-160. London: Academic.

Joseph SK, Rice HL (1989) The relationship between inositol trisphosphate receptor density and calcium release in brain microsomes. Mol Pharmacol 35:355-359.

Joseph SK, Rice HL, Williamson JR (1989) The effect of external calcium and $\mathrm{pH}$ on inositol trisphosphate-mediated calcium release from cerebellum microsomal fractions. Biochem J 258:261-265.

Kuno M, Gardner P (1987) Ion channels activated by inositol 1,4,5trisphosphate in plasma membrane of human T-lymphocytes. Nature 326:301-304.

Maeda N, Niinobe M, Mikoshiba K (1990) A cerebellar Purkinje cell marker P400 protein is an inositol 1,4,5-trisphosphate (InsP3) receptor protein. Purification and characterization of InsP3 receptor complex. EMBO J 9:61-67.

Maeda N, Kawasaki T, Nakade S, Yokota N, Taguchi T, Kasai M, Mikoshiba K (1991) Structural and functional characterization of inositol 1,4,5-trisphosphate receptor channel from mouse cerebellum. J Biol Chem 266:1109-1116.

Mallet J, Huchet M, Pougeois R, Changeux J-P (1976) Anatomical, physiological and biochemical studies on the cerebellum from mutant mice. III. Protein differences associated with the Weaver, Staggerer and nervous mutations. Brain Res 103:291-312.

Malviya AN, Rogue P, Vincedon G (1990) Stereospecific inositol 1,4,5[32 P] trisphosphate binding to isolated rat liver nuclei: evidence for inositol trisphosphate receptor-mediated calcium release from the nucleus. Proc Natl Acad Sci USA 87:9270-9274.

Marks AR, Tempst P, Chadwick CC, Riviere L, Fleischer S, NadalGinard B (1990) Smooth muscle and brain inositol 1,4,5-trisphosphate receptors are structurally and functionally similar. J Biol Chem 265:20719-20722.

McPherson PS, Campbell KP (1990) Solubilization and biochemical characterization of the high affinity $\left[{ }^{3} \mathrm{H}\right]$ ryanodine receptor from rabbit brain membranes. J Biol Chem 265:18454-18460.

Meyer T, Stryer L (1990) Transient calcium release induced by successive increments of inositol 1,4,5-trisphosphate. Proc Natl Acad Sci USA 87:3841-3845.

Meycr T, Stryer L (1991) Calcium spiking. Annu Rev Biophys Biophys Chem 20:153-174.

Meyer T, Holowka D, Stryer L (1988) Highly cooperative opening of calcium channels by inositol 1,4,5-trisphosphate. Science 240:653656.

Meyer T, Wensel T, Stryer L (1990) Kinetics of calcium channel openings by inositol 1,4,5-trisphosphate. Biochemistry 297:32-37.

Mignery GA, Sudhof TC (1990) The ligand binding site and transduction mechanism in the inositol-1,4,5-trisphosphate receptor. EMBO J 9:3893-3898.

Mignery GA, Sudhof TC, Takei K, DeCamilli P (1989) Putative receptor for inositol 1,4,5-trisphosphate similar to ryanodine receptor. Nature 342:192-195.

Mignery GA, Newton CL, Archer BT III, Sudhof TC (1990) Structure and cxpression of the rat inositol 1,4,5-trisphosphate receptor. J Biol Chem 265:12679-12685.

Mikoshiba K, Changeux J-P (1978) Morphological and biochemical studies on isolated molecular and granular layers from bovine cerebellum. Brain Res 142:487-504.

Mikoshiba K, Huchet M, Changeux J-P (1979) Biochemical and immunological studies on the $\mathrm{P} 400$ protein, a protein characteristic of the Purkinje cells from mouse and rat cerebellum. Dev Neurosci 2: 254-275.

Miyawaki A, Furuichi T, Ryou Y, Yoshikawa S, Nakagawa T, Saitoh
T, Mikoshiba K (1991) Structure-function relationships of the mouse inositol 1,4,5-trisphosphate receptor. Proc Natl Acad Sci USA 88: $4911-4915$.

Morris AP, Gallacher DV, Irvine RF, Petersen OH (1987) Synergism of inositol trisphosphate and tetrakisphosphate in activating $\mathrm{Ca}^{2+}$ dependent $\mathrm{K}^{+}$channels. Nature 330:653-655.

Mourey RJ, Verma A, Supattapone S, Snyder SH (1990) Purification and characterization of the inositol 1,4,5-trisphosphate receptor protein from rat vas deferens. Biochem J 272:383-389.

Muallem S, Pandol SJ, Beeker TG (1989) Hormone-evoked calcium release from intracellular stores is a quantal process. $J$ Biol Chem 264:205-212

Nakagawa T, Okano H, Furuichi T, Aruga J, Mikoshiba K (1991) The subtypes of the mouse inositol 1,4,5-trisphosphate receptor are expressed in tissue-specific and developmentally specific manner. Proc Natl Acad Sci USA 88:6244-6248.

Nicoletti F, Bruno V, Fiore L, Cavallaro S, Canonico PL (1989) Inositol hexakisphosphate (phytic acid) enhances $\mathrm{Ca}^{2+}$ influx and D- $\left[{ }^{3} \mathrm{H}\right]$ aspartate release in cultured cerebellar neurons. J Neurochem 53:1026-1030.

Nicotera P, McConkey DJ, Jones DP, Orrenius S (1989) ATP stimulates $\mathrm{Ca}^{2+}$ uptake and increases the free $\mathrm{Ca}^{2+}$ concentration in isolated rat liver nuclei. Proc Natl Acad Sci USA 86:453-457.

Nicotera P, Orrenius S, Nilsson T, Berggren P-O (1990) An inositol 1,4,5-trisphosphate-sensitive $\mathrm{Ca}^{2+}$ pool in liver nuclei. Proc Natl Acad Sci USA 87:6858-6862.

Nishizuka $Y$ (1988) The molecular heterogeneity of protein kinase $C$ and its implications for cellular regulation. Nature 334:661-665.

Nordquist DT, Kozak CA, Orr HT (1988) cDNA cloning and characterization of three genes uniquely expressed in cerebellum by Purkinje neurons. J Neurosci 8:4780-4789.

Otsu H, Yamamoto A, Maeda N, Mikoshiba K, Tashiro Y (1990) Immunogold localization of inositol 1,4,5-trisphosphate (InsP3) receptor in mouse cerebellar Purkinje cells using three monoclonal antibodies. Cell Struct Funct 15:163-173.

Ouimet CC, McGuiness TL, Greengard P (1984) Immunocytochemical localization of calcium/calmodulin-dependent protein kinase II in rat brain. Proc Natl Acad Sci USA 81:5604-5608.

Peng Y-W, Sharp AH, Snyder SH, Yau K-W (1991) Localization of inositol 1,4,5-trisphosphate receptor in synaptic terminals in the vertebrate retina. Neuron 6:525-531.

Petersen OH, Wakui M (1990) Oscillating intracellular $\mathrm{Ca}^{2+}$ signals evoked by activation of receptors linked to inositol lipid hydrolysis: mechanism of generation. J Membr Biol 1 18:93-105.

Prestwich GD, Marecek JF, Mourey RJ, Theibert AB, Ferris CD, Danoff SK, Snyder SH (1991) Tethered IP ${ }_{3}$ synthesis and biochemical applications of the 1-O-(3-aminopropyl) ester of inositol 1,4,5-trisphosphate. J Am Chem Soc 113:1822-1825.

Ross CA, Meldolesi J, Milner TA, Satoh T, Supattapone S, Snyder SH (1989) Inositol 1,4,5-trisphosphate receptor localized to endoplasmic reticulum in cerebellar Purkinje neurons. Nature 339:468-470.

Ross CA, Danoff SK, Ferris CD, Donath C, Fischer GA, Munemitsu S, Snyder SH, Ullrich A (1991) Inositol 1,4,5-trisphosphate receptors (IP3R): cloning of the human cDNA and an IP3R-related mouse cDNA indicating a family of IP3R-related genes. Soc Neurosci Abstr 17.

Satoh T, Ross CA, Villa A, Supattapone S, Pozzan T, Snyder SH, Meldolesi J (1990) The inositol 1,4,5-trisphosphate receptor in cerebellar Purkinje cells: quantitative immunogold labeling reveals concentration in an ER subcompartment. J Cell Biol 111:615-624.

Smith CD, Cox CC, Snyderman R (1986) Receptor-channel activation of phosphoinositide-specific phospholipase $\mathrm{C}$ by an $\mathrm{N}$ protein. Science 232:97-100.

Smith JB, Smith L, Higgins BL (1985) Temperature and nucleotide dependence of calcium release by myo-inositol 1,4,5-trisphosphate in cultured vascular smooth muscle cells. J Biol Chem 260:1441314416.

Spat A, Bradford PG, McKinney JS, Rubin RP, Putney JW Jr (1986) A saturable receptor for ${ }^{32} \mathrm{P}$-inusitol-1,4,5-trisphosphate in hepatocytes and neutrophils. Nature 319:514-516.

Streb H, Irvine RF, Berridge MJ, Schulz I (1983) Release of $\mathrm{Ca}^{2+}$ from nonmitochondrial intracellular store in pancreatic acinar cells by inositol-1,4,5-trisphosphate. Nature 306:67-69.

Sudhof TC, Newton CL, Archer BT III, Ushkaryov YA, Mignery GA (1991) Structure of a novel InsP3 receptor. EMBO J 10:3199-3206. 
Supattapone S, Danoff SK, Theibert A, Joseph SK, Steiner J, Snyder SH (1988a) Cyclic AMP-dependent phosphorylation of a brain inositol trisphosphate receptor decreases its release of calcium. Proc Natl Acad Sci USA 85:8747-8750.

Supattapone S, Worley PF, Baraban JM, Snyder SH (1988b) Solubilization, purification, and characterization of an inositol trisphosphate receptor. J Biol Chem 263:1530-1534.

Takeshima $\mathrm{H}$, Nishimura S, Matsumoto $\mathrm{T}$, Ishida $\mathrm{H}$, Kangawa $\mathrm{K}$, Minamino N, Matsuo H, Ueda M, Hanaoka M, Hirose T, Numa S (1989) Primary structure and expression from complementary DNA of skeletal muscle ryanodine receptor. Nature 339:439-445.

Theibert AB, Supattapone S, Worley PF, Baraban JM, Meek JL, Snyder SH (1987) Demonstration of inositol 1,3,4,5-tetrakisphosphate receptor binding. Biochem Biophys Res Commun 148:1283-1289.

Theibert AB, Estevez VA, Ferris CD, DanoffSK, Barrow RK, Prestwich GD, Snyder SH (1991) Inositol 1,3,4,5-tetrakisphosphate and inositol hexakisphosphate receptor proteins: isolation and characterization from rat brain. Proc Natl Acad Sci USA 88:3165-3169.

Theibert AB, Estevez VA, Mourey RJ, Marecek JF, Barrow RK, Prestwich GD, Snyder SH (1992) Photoaffinity labeling and characterization of purified inositol 1,3,4,5-tetrakisphosphate and inositol hexakisphosphate receptor proteins. J Biol Chem, in press.
Vallejo M, Jackson T, Lightman S, Hanley MR (1987) Occurrence and extracellular actions of inositol pentakis- and hexakisphosphate in mammalian brain. Nature 330:656-658

Verma A, Ross CA, Verma D, Supattapone S, Snyder SH (1990) Rat brain endoplasmic reticulum calcium pools are anatomically and functionally segregated. Cell Reg 1:781-790.

Vilven $J$, Coronado $R$ (1988) Opening of dihydropyridine calcium channels in skeletal muscle membranes by inositol trisphosphate. Nature 336:587-589.

Walaas SI, Lai Y, Gorelick FS, DeCamilli P, Moretti M, Greengard P (1988) Cell-specific localization of the alpha-subunit of calcium/calmodulin-dependent protein kinase II in Purkinje cells in rodent cerebellum. Brain Res 464:233-242.

Worley PF, Baraban JM, Colvin JS, Snyder SH (1987a) Inositol trisphosphate receptor localization in brain: variable stoichiometry with protein kinase C. Nature 325:159-161.

Worley PF, Baraban JM, Supattapone S, Wilson VS, Snyder SH (1987b) Characterization of inositol trisphosphate receptor binding in brain. Regulation by pH and calcium. J Biol Chem 262:12132-12136.

Worley PF, Baraban JM, Snyder SH (1989) Inositol 1,4,5-trisphosphate receptor binding: autoradiographic localization in rat brain. $J$ Neurosci 9:339-346. 